\title{
THE CRIMINAL TWILIGHT ZONE: PRE-TRIAL PROCEDURES IN THE 1840'S
}

\author{
W. WESLEY PUE*
}

The following article focuses upon an acclaimed piece of reform legislation in the area of pretrial procedures, contrasting the expectations and perceived accomplishments of the legislation with the actual reform achieved. The comparison reveals some of the pitfalls and compromises involved in introducing legislation within a controversial area of law. In addition, the author provides an interesting analysis of the law regarding pre-trial procedures in the 1840's through the criticisms offered to the legislators by the legal community at that time.

\section{SIR JOHN JERVIS' ACTS}

Her Majesty's present Attorney-General ${ }^{1}$ has, by these Acts, ${ }^{2}$ done more for the due administra. tion of criminal justice throughout England, than has ever yet been done by any person, with the single exception perhaps of Sir Robert Peel. Even the statutes called Peel's Acts, although well designed, well executed, must yield the palm of real down-right ultility of these Acts: Peel's Acts gave with certainty the definitions of the different offences in the nature of larceny and malicious mischief; Lord Lansdowne's Acts, those relating to offences against the person; but these Acts created a whole code of practise for Justices of Peace out of session, both with relation to indictable offences generally, and to summary convictions and orders, and provide for the fair and reasonable indemnity of these same Justices in the execution of their several duties. And when we consider that more than half of the criminal law of England is administered by Justices of the Peace out of sessions, we may learn to estimate and appreciate the importance of these Acts, which give the greatest facility to the Justices in the execution of their very onerous duties, enable them to execute them with certainty and correctness, create a uniformity of practice in this respect throughout the kingdom, and give a fair and reasonable protection, and consequent confidence, to Justices in their administration of the law. Nothing has hitherto been attempted, which is likely to have so beneficial an effect on the administration of the criminal law of the country, as these three Acts. They insure the administration of it in the true English spirit of fairness towards the accused, at the same time that they repress and punish the crime with certainty, and give every fair and necessary security and protection to those to whom the duty of doing this is entrusted.

It was thus that John Archbold, Barrister-at-law, welcomed the enactment of "Jervis's Acts" in 1848. " The legislation, praised even beyond that of Sir Robert Peel, was noted by Archbold as praiseworthy in three general ways:

1. It created a "whole code or practice for Justices of Peace out of session", resulting in "uniformity of practice . . . throughout the kingdom" in the courts which administered "more than half of the criminal law";

2. It provided for a "fair and reasonable indemnity" "and consequent confidence, to Justices in their administration of the law";

* M.A., LL.M. Of the Bars of Alberta and the Northwest Territories. The author is a lecturer at Osgoode Hall Law School. Thanks are due to Professor Douglas Hay who both inspired this project and was kind enough to review a preliminary draft. He is, of course, entirely blameless for errors that remain.

1. "Her Majesty's present Attorney-General" was Sir John Jervis.

2. 11 \& 12 Victoria, cc. 42, 43, 44. Eighth Report of Her Majesty's Commissioners on Criminal Law, H.M.S.O.,(1845). Henceforth, the Report will be referred to as the "Law Commissioner's VIIIth Report". Footnoted references which state simply a person's name followed by a number in parentheses refer to written submissions reproduced as appendix ' $A$ ' to this report. The numbers in parentheses are page numbers in the original report which is reproduced in full in Volume 4 of the Irish University Press Series of British Parliamentary Papers.

3. John Frederick Archbold, Jervis's Acts (1848). The phrase "Sir John Jervis' Act" is used here and henceforth to refer only to 11 \& 12 Vict., c. 42.

4. Id, Preface (a). 
3. It ensured that Criminal law would be administered by Justices of the Peace "in the true English spirit of fairness towards the accused" while, at the same time "repress[ing] and punish[ing] the crime with certainty".

The present paper has, as its object the restricted goal of discussing the first of Sir John Jervis's Acts, "an act to facilitate the Performance of the Duties of Justices of the Peace out of Sessions within England and Wales with respect to Persons charged with indictable offences." 5 As such the question of whether the third of the Jervis Acts indeed created a "fair and reasonable indemnity for Justices of the Peace is not in issue. Nor is it intended to dispute that the legislative trilogy created in effect a "whole code of practice" which may (and the point is conceded for the purposes of this discussion) have resulted in "uniformity of practice" throughout England and Wales.

The discussion here is confined therefore to the questions of whether the first of the Jervis Acts created a scheme which was such as to ensure that the twin goals of "fairness towards the accused" and the certain repression and punishment of crime were achieved. The Act has been welcomed by many as heralding a new standard of fairness in preliminary examinations and, indeed, as creating the preliminary inquiry as it is known to modern lawyers. It has been praised as revolutionary both for easing the difficulties of prosecution ${ }^{6}$ and for creating a new legal norm of fair play in preliminary inquiries. ${ }^{?}$

Such claims are extravagent in the extreme. It may well be that the legislation of 1848 was the most that could be achieved given the political climate of the day. That, however, is a question of causation which is logically distinct from the question here in issue: the effect of 11 \& 12 Vict. c.42. Far from being a radical enactment, that statute was conservative in the deepest sense of that word. It simply re-enacted and consolidated existing law, both statutory and court made, neither easing the burden of prosecutors nor creating new procedural protections for the accused at preliminary inquiries. The most radical innovations (if there were any at all) simply made "law" of existing court "practices". 8

5. $11 \& 12$ Vict. c. 42 .

6. Supran. 3.

7. This view is most explicitly stated by W.J.V. Windeyer in his Legal History (1938) at 111:

It was not until the first of $\mathrm{Sir}$ John Jervis's Acts that an inquisitorial examination of accused persons by a justice and private hearings of witnesses for the prosecution were replaced by the present system, in which the depositions of witnesses are taken in the presence of the accused, who can, in a proper case, be committed for trial before a jury without being compelled to make any statement against his will. Similar views are, to greater or lesser degree, reflected in: Edward Jenks, $A$ Short History of English Law (5th ed. 1938) at 348; Sir William Holdsworth, 15 A History of English Law (1965) 161-162; W.R. Cornish, "Defects in Prosecuting-Professional Views in 1845" in Reshaping the Criminal Law (P.R. Glazebrook ed., 1978) at 311; John H. Langbein, Prosecuting Crime in the Renaissance (1974) at 74.

8. Quaere: Whether "law" and predominant "practice" can be meaningfully distinguished in a common law system? 


\section{PRE-TRIAL PROCEDURES}

Pre-trial procedures in $1843^{\circ}$ were manifold. In the event of an alleged homicide the first proceeding would likely be a coroner's inquest. If a verdict of murder or manslaughter was arrived at, the accused might be sent to trial on the coroner's inquisition alone. These, however, were often found to be insufficiently clear as to the commission of the offence and were frequently quashed for technical defects. ${ }^{10}$

A cautious prosecutor would, therefore, usually follow the coroner's inquest by preferring an indictment before a grand jury ${ }^{11}$ (usually, but not always, ${ }^{12}$ the proceedings before a grand jury would have followed a preliminary inquiry before a magistrate ${ }^{13}$ ). In the event that the grand jury ignored a bill preferred the accused could be sent to trial on the coroner's inquisition alone, the prosecutor taking his chances on the adequacy of the coroner's inquisition.

Where the coroner's inquisition turned out to be defective the prosecution would have then failed both before a grand jury and before the trial judge. The issues for resolution were, of course, quite different in the two tribunals, the grand jury having decided merely that no prima facie case had been made against the accused on the evidence before them, while the trial judge had simply quashed an inquisition for technical defect of form.

Neither decision was such as to raise a plea of autrefois, res judicata or issue estoppel on the merits of the charge. Accordingly, it would seem that the prosecutor was, under the criminal procedure of the time, able to proceed yet again against his victim. A quashed coroner's inquest could not be brought back to life and the matter could be carried to a public forum only if a grand jury either made a presentment in its own right or found a true bill preferred before them.

Thus, the prosecution of an extreme case might have proceeded through the following stages:

1. Coroner's Inquest (verdict of manslaughter) ${ }^{14}$

2. Inquiry before Magistrate (committal on manslaughter)

3. Bill preferred before Grand Jury (returned Ignoramus)

9. Supra n. 2.

10. Supran. 3.

11. In submissions to the English Law Commissioners, H. Stuart Roupell ("Eighth Report of Her Majesty's Commissioners on Criminal Law", H.M.S.O., (1845) 339) states as follows:

But it is, I believe, generally considered inexpedient to dispense with the indict. ment upon the coroner's inquisition, because if the former indictment were quashed, i.e. for any error or irregularity, the prisoner may still be put upon his trial by the latter. This is illustrated by the case of $R$. v. JONES AND BUCK [sic.] . . . This case is reported as $R$. v. Jones and Bick (1843) 1 Car. \& K. 243, 174 E.R. 793. See also The Times, 14 Oct., 1843, at 3 , col. 3.

12. A further discussion of grand jury procedures follows, infra

13. As will appear from the discussion following, the magistrates of the day conducted only a very rudimentary preliminary inquiry.

14. Wherever a verdict of murder or manslaughter was found by a coroner's jury the inquisition was regarded as an indictment (Law Commissioners VIIIth Report, Ch. II, Sect. 5, Art. 19, p. 92; $R$. v. Grand Junction Railway, T. T. 1838; Coroner's P. 63). In practice, however, a bill was almost invariably preferred to a Grand Jury because Coroner's inquisitions were notorious for their technical defects. See discussion, infra. 
4. Matter brought before court on Coroner's Inquest (quashed on preliminary motion)

5. Inquiry before Magistrate (committal on manslaughter or murder)

6. Bill preferred before Grand Jury ("true bill" found)

7. Trial

\section{MATTERS PRELIMINARY TO TRIAL IN 1843}

The personal freedom and reputation of accused persons would suffer from the time a summons or warrant was issued to bring them before a magistrate for preliminary inquiry. ${ }^{15}$ They would clearly be concerned about such charges and would have to bear the expense of organizing defences for the anticipated trial. Nevertheless, under the criminal procedure established by English law in 1843 they would be assured of only the most rudimentary opportunity to state their cases prior to trial.

The coroner's jury, acting in haste, and having the duty only "to hear evidence on all hands if it be offered them and upon oath" ${ }^{16}$ could not be expected to seek out and hear the case of one against whom they had formed a tentative conclusion. ${ }^{17}$

When the matter came before a magistrate for a preliminary inquiry the accused would have a right to be present when depositions were taken and to cross-examine witnesses against him ${ }^{18}$ but this did not mean that he would inevitably be present for the initial hearing and sifting of evidence from which depositions eventually grew. ${ }^{19}$ The depositions themselves might take the character of rather sketchy notes of the tendency of the evidence. ${ }^{20}$ Moreover, a magistrate making the preliminary decision whether to discharge a prisoner, commit him to jail, or admit to bail, was under no duty to hear any evidence whatsoever

15. With regard to personal freedom, it should be noted that bail was less widely available in 1843 than it is at present. In cases of felony, bail could only be granted by two or more justices. The standard established by 7 Geo. IV, c. 64, s. 1 was cited in the Law Commissioners, VIIIth Report, Ch. I, Sect. 7, Art. 2, p. 50, as follows:

[If] the evidence given in support of the charge shall, in their opinion, not be such as to raise a strong presumption of the guilt of the person charged, and to require his committal; or such evidence shall be adduced on behalf of the person charged as shall in their opinion weaken the presumption of his guilt, but there shall notwithstanding appear to them in either of such cases sufficient ground for judicial inquiry into his guilt, the person charged shall be admitted to bail by two such justices....

In $R$. v. Richard Andrews(1844) 2 Dow. \& Ry. 10, it was said that bail cannot be granted to one against whom a bill for murder has been found by a grand jury. In other cases the test is whether the court "can judge of the probable guilt or innocence of the person" (at p. 12).

16. Law Commissioners VIIIth Rep., Ch. II, Sect. 5, Art. 6, p. 91; 2 Hale, 157.

17. Richard Johnson, Law Commissioners VIIIth Rep., 319.

18. Law Commissioners VIIIth Rep., Ch. I, Sect. 7, Art. 29, 31; 1 Chitty's C.L. 79.

19. J. P. Cobbett, Law Commissioners VIIIth Rep., 293; Mr. Browne (id. at 314) reports that depositions were sometimes taken privately and then read over quickly to the prisoner and witnesses in circumstances such that the prisoner was "unprepared for attending them properly". See submissions of P. Bingham (223), S. Temple (232), R.E. Broughton (238), Thomas Paynter (244).

20. This complaint is made in the submissions to the Law Commission of E. Ludlow (213), John Mellor (227), and J.P. Cobbett (293). See also Law Commissioners VIIIth Report, Ch. I, Sect. 7, Art. $5,6$. 
tendered by the accused ${ }^{21}$ (though there was a duty to ask the accused "what he has to say against the charge")"22.

Throughout the whole of the preliminary inquiry an accused person might be forced to rely upon his own abilities in making his case, unaided by counsel or attorney. The law in this respect was stated by the English Law Commissioners as follows: ${ }^{23}$

The accused is not entitled as of right to the assistance of an attorney or counsel on a charge of felony; the permitting such assistance is discretionary with the magistrate or court.

It would seem that magistrates frequently (if not usually ${ }^{24}$ ) exercised their discretion against an accused's right to legal assistance. ${ }^{25}$

The magistrate himself might be biased against the accused ${ }^{26}$, ignorant of the law ${ }^{27}$, and might subsequently don the hat of a prosecutor ${ }^{28}$ or sit as a trial judge in the very case he had committed ${ }^{29}$. He would be assisted by a clerk who, in addition to quite possibly being either incompetent ${ }^{30}$ or biased, ${ }^{31}$ was paid by fees based on the number of committals ${ }^{32}$ and who could look forward to remuneration for conducting prosecutions in the vast majority of cases sent to trial from his court. ${ }^{33}$

The matter would then come before a grand jury who would make a hasty decision ${ }^{34}$ following an ex parte ${ }^{35}$ hearing of secret evidence ${ }^{36}$ which might be mustered and presented by counsel or attorney for the prosecu-

21. Law Commissioners VIIIth Report, Ch. I, Sect. 7, Art. 4, 25, 26; 7 Geo. IV, c. 64, s. 1; 3 Maule \& Sel. 1; Dalt, J. 164; 1 Chitty's C.L. 77, citing 3 Inst. 79; 1 Ann St. 2 c.9; 4 Black Comm. 359; Chitty's Burn's Just., "Examinations by Justices Before Trial".

22. Law Comms. VIIIth Rep., Ch. I, Sect. 7, Art. 32. Even this minimal duty was sometimes not met: John Mellor (227); R. Read (291).

23. Law Comms. VIIIth Rep., Ch. I, Sect. 7, Art. 34; Steph. C.L. 251; Chitty's Burn's J., "Examination by Justices Before Trial"; 2 Dow \& Ry 86.

24. R. E. Broughton (238); Thomas Paynter (244); Mr. Coke (309); Richard Johnson (319).

25. W. Grantham (273); Thomas Palton (277); W. H. Owen (278); Thomas Attwood (279); R. Read (291); J. P. Cobbett (293); R. S. Sowler (333).

26. R. Leigh (226); Edward Coxwell (256); C. N. Hastie (324); J. J. Lowndes (333).

27. J. Stammers (215); John Morland (259); John Mercer (268); James Richardson and Hamilton Richardson (270); William Downes (279); J. Stone (300); F. Newman Rogers (302); Mr. Browne (314).

28. J. Rooker (267).

29. James Beesley (317).

30. James Richardson and Hamilton Richardson (270); R. S. Sowler (333).

31. R. S. Sowler (333).

32. Edward Coxwell (256); John Morland (259); Justices Clerks Society (319); William Trotter (330); R. W. Sowler (333).

33. W. T. Paris (254); J. Rooker (267); J. Eyton (274); William Downes (279); Robert Poole (290); Robert Brandt (303); Mssrs. Brooke \& Hall (311); Mr. Browne (314); J. M. Blagg (325); R. S. Sowler (333).

34. S. R. Bosanquet (228); R. E. Broughton (238); John Woodhouse (278); Justices Clerks Society (319).

35. The ex parte nature of Grand Jury proceedings is criticized by: Sir G. A. Lewin (220); P. Bingham (223); Thomas Paynter (244); J. Roscoe (251); Mr. Holding (290); J. M. Blagg (325).

36. Law Comms. VIIIth Rep., Ch. II, Sect. 2, Art. 67; 2 Hale 161; Chitt. C.L. 317; 4 Black. Comm. 126. Such secrecy is objected to by the following: J. Barstow (222); Mssrs. Philcox and Baldock (329); Thomas Paynter (244); Mr. Holding (290); J. M. Blagg (325); William Adams (342); and praised by J. L. Adolphus (336). 
tor $^{37}$. A grand jury was not obliged to hear any defence evidence whatsoever ${ }^{38}$. If, despite these "precautions", the jury was inclined to return a bill ignoramus, there was a possibility that they might be persuaded of the eminent reasonableness of the committal by no less a person than the committing magistrate who might himself sit on the grand jury ${ }^{39}$ If doubt remained, the issue might be resolved in favour of returning a "true bill" simply because of class bias. ${ }^{40}$

\section{PLIGHT OF AN ACCUSED PERSON}

It has been noted that under the criminal procedure of 1843 accused persons might have faced as many as six "judicial" inquiries preliminary to their trial. Such proceedings might have taken a period of months, or even years. ${ }^{41}$ During this period they would be shunned and feared by acquaintances and friends. Most probably they would be imprisoned awaiting trial. ${ }^{42}$ Even if eventually acquitted they would have a very difficult time living down the findings of the preliminary tribunals. Nonetheless, at no time prior to trial were the accused assured of even the most rudimentary opportunity to disabuse their judges of any misapprehensions created by the evidence adduced for the prosecutor. They lived in a legal twilight zone, neither guilty at law nor treated as innocent; suffering penal consequences while "presumed" innocent and never permitted to make adequate answer to the charges against them until trial.

Clearly, then, the prosecutorial procedure of England was ripe for reform by the time of Sir John Jervis' Acts in 1848. Given the operation of proceedings preliminary to trial it might reasonably be thought that the

37. Law Comms. VIIIth Rep., Ch. II, s.1, Arts. 69, 70; kel. 8; 1 Chitty's C.L. 317; 12 vin. Ab. 38; Hawk P.C., b.2, c.46, s.93, ed. by Leach; Tri per pais, 387; Coroner's P. 123. This practice is heartily endorsed by $R$. Almack (272) and its infrequent use lamented by Thomas Barneby (343). The Justices Clerks Society (319) however had some doubts as to the propriety of this prosecutorial "assistance" to the grand jury.

38. Law Comms. VIIIth Rep., Ch. II, s.1, Art. 54; 1 Chitty's C.L. 317. The disregard for the case of the accused is criticized by J. Roscoe (251) and James Beesley (317).

39. R. Almack (272) considers the presence of the committing magistrate on a grand jury to be an extremely fortuitous circumstance which helps to prevent criminals from escaping. See text to $\mathrm{n} .29$ supra. Theoretically, it would seem to have been possible for one man to sit as Justice of the Peace at a preliminary inquiry, as a member of the grand jury and as a trial judge at petty sessions in the same matter!

40. Class bias, apparently, operated as a two-edged sword. S. R. Bosanquet (228) says it is "frequently prejudicial and unjust to innocent persons", while J. P. Cobbett (293) expresses the opinion that the greatest evil of the grand jury system is their tendency to find "no bill" in cases involving "people of their own class". Conversely, J. L. Adolphus (336) somewhat cryptically praises the grand juries for finding "no true bill" on cases "which had better not be public."

41. The outside limit (assuming immediate commital by a magistrate and the finding of a true bill on the first time the matter was brought before a grand jury), and one probably never actually achieved in the period under consideration, is indicated by S. R. Bosanquet (228) who says the grand jury was "formerly" necessary "to save innocent persons from lengthened imprisonment till the coming of the justice in eyre, perhaps at the end of three years." S. Greetham (276) suggests it was not uncommon for cases to be postponed to the next sessions.

42. On the restricted availability of bail, see $n .5$ supra. W. Barker (330) suggests that an accused might be "in prison for months" before his case was even put to the grand jury. Outside of the Metropolitan Districts magistrates apparently had no power to bail during the period of adjournments in a preliminary inquiry before magistrates; Thomas Griffin (312) speaks of innocent men being imprisoned for four months awaiting trial. 
major impetus for change arose from the unfairness of the system to accused persons.

This was not, however, the case. In 1843 the English Law Commissioners circulated a series of questions ${ }^{43}$ concerning the procedure followed in criminal prosecutions. Some 97 written submissions were received from persons in the legal profession of which 87 contained comments upon matters preliminary to trial. There was, in addition, oral evidence from two sources ${ }^{44}$ and the questions put by the law commissioners resulted in two articles being printed in learned journals..$^{45}$ If this documentary evidence may be taken as representative of the views of legal opinion-makers at the time ${ }^{46}$ it would seem that the unfairness of the then-current system of preliminary inquiry in criminal matters was only one of a number of concerns - often conflicting - which militated for reform.

It is proposed to isolate and analyse these various concerns and to relate them to the reforms which were eventually enacted in "An Act to facilitate the Performance of the Duties of Justices of the Peace out of Sessions within England and Wales with respect to Persons charged with indictable offences". ${ }^{47}$ In particular, it is hoped that this paper will demonstrate:

1. That the steps taken were not necessarily motivated solely by a liberal wish for fairness to accused parties;

2. That the legislative reforms were selected from a broad range of proposals (many of which might reasonably have been expected to achieve the desired results in varying degrees) and were selected exclusively from the most conservative end of the spectrum.

\section{PURPOSES OF "PRELIMINARY INQUIRIES"}

In discussing the various concerns felt about preliminary inquiries by the English legal profession in the 1840's it is important to remember that the term "preliminary inquiry" did not then carry the fixed and certain meaning which is now current. The phrase was indeed frequently used to refer to the procedure of bringing an accused before a magistrate prior to committal or bail. It also had a broader sense however. "Preliminary inquiries" used in this second way might refer to all official inquiries which preceded trial from the investigations of a police constable or coroner through the magistrates examinations to the hearing by a grand jury. ${ }^{48}$

The submissions made to the Law Commissioners in 1843 reflect a considerable confusion on the part of the legal profession as to whether

43. Law Comms. VIIIth Rep., at 209.

44. Law Comms. VIIIth Rep., Appendix B, William Samuel Jones (344), C.A. Smith and others (645).

45. J. Pitt Taylor, "Defects of Criminal Procedure" Law Magazine LXIV; J. Pitt Taylor, "On the Writ of Certiorari in Criminal Cases" I Law Review. Both articles are reproduced as appendix " $C$ " of the Law Comms. VIIIth Report, at $357 \mathrm{ff}$.

46. The views thus recorded are not, of course, representative in the same sense of a modern opinion poll based on random or strata sampling techniques. It might be assumed, however, that those persons most concerned about criminal procedure were most likely to make submissions. If so, their written submissions provide a valuable window on the minds of the most influential (because most active in disseminating their views) persons of the time.

47. $11 \& 12$ Vict. c. $42(1848)$. 
there were distinct purposes for each of these over-lapping pre-trial investigations. Each stage of the process (and much more the overall scheme) was subjected to severe criticism. When reform was discussed the suggestions were many and varied, the fluidity of the various pre-trial investigations giving rise to as many ideas for reform as there were objections to the existing system.

Taken as a whole the submissions made to the Commissioners on Criminal law reflect an inherent tension between two main purposes of the criminal process. This tension, which is one common to most judicial and administrative processes, is that of attempting to reconcile the need for efficiency with a desire to exhibit fairness to the person most directly affected (the accused). The discussions of the 1840's reveal a widely held belief that preliminary inquiries (using that term in its broadest sense) had two main purposes:

1. To act as a sieve so as to ensure that matters were properly prepared before going to trial. The object here was to encourage mustering of prosecution evidence and to see to it that the proper formal documents were prepared prior to trial. The fear was that without a thorough pre-trial review of evidence and the drawing of a proper indictment guilty parties would escape justice simply because of inadequate prosecution or because of mere technicality.

2. To stop frivolous, vexatious, or merely misguided prosecutions before they could do irreparable harm to innocent accused. ${ }^{49}$

It will be noted that these two purposes can be complimentary in operation. If the evidence is organized in such a way as to more or less ensure conviction at trial it is unlikely that the action would be characterized as frivolous, vexatious or misguided. The common belief that these two purposes could be effectively pursued through the same tribunal is reflected in the view of R.S. Sowler: $:^{50}$

The preliminary inquiry before the magistrates on criminal charges appears to be well adapted to the purpose for which it was originally instituted - viz., to prevent the incarceration of the innocent as far as possible, and to sift and arrange the evidence against the guilty.

Once this relationship is acknowledged it will be understood that reforms which apparently seek to increase procedural fairness to the accused may in fact be largely motivated by a desire to enhance the efficiency of prosecutions so as to ensure his ultimate conviction. There is, for example, cause to wonder exactly what factor was foremost in George

48. One such use of the term is illustrated in the submissions of E.E. Deacon (216) who says: "After the facts of a case have been properly sifted in one preliminary inquiry, I think that a prosecutor should not be further troubled until he is called upon to give his evidence in the Court which is finally to decide upon the guilt or innocence of the accused party. It follows, therefore, that the finding of a bill by a grand jury might be conveniently disposed with after a previous inquiry before the committing magistrates ...." (the emphasis is Deacon's); Beesley (317); the Law Commissioners themselves use the phrase in this second sense: Law Comm. VIII Rep. at 209, Q. 2.

49. These categories might be expanded by the addition, for example, of pre-trial disclosure or of the drawing of the formal charge as "objects". It would seem, however, that any further objects might fairly be characterized as logically falling within the two enumerated. For the sake of brevity and clarity I have refrained from enumerating subcategories ad infinitum.

50. R.S. Sowler (333). 
Wilkinson's mind in recommending the institution of an identification procedure akin to the modern police "line-up":"51

These observations may appear to be mainly addressed to the object of favouring the acquittal of prisoners; but I think that such regulations, by disarming counsel for prisoners of many of the topics most popular and attractive with juries, would, in effect, greatly conduce to the conviction of the really guilty; and, after all, it is a cogent (if old-fashioned) reason in favour of such regulations, that it is better for ten guilty to escape than for one innocent to suffer.

The conflicting rationales for Wilkinson's proposed reforms run together to such an extent that it is impossible to be sure whether he was motivated primarily by a liberal concern for accused persons and simply "threw in" the "more-certainty-of-conviction" argument as a sop to his prosecutionoriented colleagues or vice-versa.

The relative emphasis which a particular judicial officer places on the one or the other object will however greatly affect the procedure followed. The greater the degree of emphasis placed on preliminary procedure as an aid to prosecution the less likely it is that the case for the accused will be explored in depth at the pre-trial inquiries. Similarly, both perception of flaws in an existing system and recommendations for reform will vary in accordance with the portion of the ideological spectrum on which the observer or critic stands.

Bearing this in mind I will attempt to illustrate the criticisms and calls for reform that emanated from either end of this spectrum.

\section{THE "EFFICIENT PROSECUTION" LOBBY}

\section{A. IRRESOLUTE PROSECUTORS}

In 1843 there was no Crown Attorney, no Director of Public Prosecutions, no public official whatsoever to guide the great bulk of criminal prosecutions through the courts. The responsibility rested with the injured party who may or may not have been intellectually or financially equipped to prosecute effectively. It is not surprising therefore that the inefficiency with which prosecutions were conducted was a cause of frequent complaint by actors in the judicial process. Thus, for example, S.R. Bosanquet, Barrister-at-law, complained that private prosecutions failed because of "neglect, collusion, ignorance". ${ }^{52}$ Lord Denman, L.C.J., expressed his concern in somewhat stronger terms: ${ }^{53}$

The injured party may be helpless, ignorant, interested, corrupt. He is altogether irresponsible; yet his dealing with the criminal may effectually defeat justice.

J. Rooker, Clerk of the Peace, expressed the view that the problem would be very serious indeed, save only for "the common practice of [prosecutions] being undertaken by the magistrates clerks . . .."!

The problem is, of course, partly a result of the natural reluctance of private citizens to involve themselves in the court process, enhanced in the

51. George H. Wilkinson (241). In 1817, Mary Shelly in her novel Frankenstein expressed a somewhat more cynical (accurate?) view of the principles motivating European law when she makes her main character say of the execution of Justice: " . . it is decided as you may have expected; all judges had rather that ten innocent should suffer, than that one guilty should escape."

52. S.R. Bosanquet (228).

53. Lord Denman (211).

54. J. Rooker (267). 
1840 's, no doubt, by the fact that a prosecution might go "wrong" at any of several stages before trial had been reached. Even when a prosecution had been commenced and a lawyer retained to see to it that technical and evidentiary hurdles were cleared there was, apparently, no certainty that prosecutions would be well, or even ethically, conducted. The lawyer's role was not always salutary.

Thus where an injured party was poor, he would have to finance his prosecution from county or town allowances which were often "so small as to render it beneath a respectable attorney's attention." was that, after "strong solicitation" 56 poor lawyers were frequently appointed to prosecute. One Nottingham Solicitor informed the Commissioners on Criminal law that ${ }^{57}$

... a set of needy, sharkish, and often unprincipled practitioners, hunt up cases of this kind. . . . and being intent only on the money to be gained, the cases are got up in a slovenly and ineffectual manner, and guilty parties escape conviction.

It was the view of at least one magistrate's clerk that the deleterious effect of "attorneys in low practice" cut both ways, at once resulting in the acquittal of the guilty, and in the encouragement of "cases of trifling description . . . which should never come before a Court." 58 Persons making an initial decision as to whether or not to prosecute were, no doubt, influenced by a concern for their "liability (in case of discharge by the justices on the preliminary inquiry) to an action for false imprisonment at the instance of a needy and reckless delinquent, urged on by unprincipled attorneys." 59

Such "unprincipled practitioners" apparently went even further in disrupting the machinery of criminal justice, for there is evidence that lawyers not infrequently accepted prosecutions intending to lose the case so that their criminal acquaintances might escape: ${ }^{60}$

In most large towns there are attorneys, who are in some degree connected with thieves, receivers of stolen goods, and such like parties; now these gentlemen, being unrestricted by any feelings of propriety, generally have in their employ or pay persons who act the jackall, and receive a small gratuity for each prosecution they bring into the hands of the attorney. It may at once be imagined how easy it is to break down a really good case, yet secure all the pecuniary profits of the prosecution, and at the same time oblige a client by obtaining the acquittal of his friend or companion. This, I have no doubt is frequently done.

Even the bona fide prosecution, earnestly commenced and conducted by a good and ethical attorney was likely to be compromised. J. Stone thought that "charges are now frequently made, and through the intercession of friends and perhaps occasionally by criminal arrangement, the person making the charge does not appear to press it against the accused."

55. Mr. Browne (314); The Law Commission, at page 25 of their VIIIth Report, warned: "If costs be too much straitened, there is great danger that the management of criminal business will fall into the hands of persons incompetent to the discharge of the duty, and unscrupulous as regards the manner of conducting it."

56. Robert Brandt (303).

57. Mr. Browne (314).

58. William Trotter (330).

59. Justices' Clerks Society (320).

60. Mr. Browne (314); see also J.M. Blagg (325).

61. J. Stone (301). The Justices Clerks Society (320) thought that prosecutors would occasionally "connive at a perversion of the law with a view to favour the escape of a culprit" in order not to appear vindictive. 
Another contributor suggested that "bribing the prosecutor" was not uncommon, and it might be expected that even the most determined of injured parties would become open to bribery as the seemingly interminable criminal process wore on: ${ }^{62}$

[Prosecutors] frequently become tired of their three attendances before the magistrate, the grand

jury, and the court, and declare that they will never prosecute again if they can avoid it.

Then too, expense of prosecution - particularly in cases where no costs were allowed from the rates - was such as to make a financial settlement of a criminal matter attractive to the aggrieved party and it is likely that the courts themselves would turn a blind eye to such compromises. There can be little doubt as to the meaning of the Chairman of Westminster Sessions when he wrote to the Law Commissioners: ${ }^{63}$

The hardship of not being able to allow expenses in cases of common assault is felt so strongly at

Sessions that it perpetually induces that hazardous practice of allowing the defendant to speak to the prosecutor.

There was then one very fundamental criticism of the prosecution of crime in the 1840's which the "prosecutorial lobby" considered to be of great importance. It was, quite simply, that prosecutions were too infrequently commenced, too irresolutely pursued, and too often compromised. Two observations must be made before proceeding to consider other criticisms made from this end of the ideological spectrum. First, it will be seen that these lawyers moved from one piece of neutral empirical evidence the fact that prosecutions were often compromised before trial - to the conclusion that guilty persons were escaping justice. They made little mention of the fear which greatly concerned some of their colleagues that frivolous or vexatious prosecutions might be commenced primarily with the intent to compromise for pecuniary benefit. This is a point to which I shall return later.

Second, it will be observed that this line of criticism focuses to a very great extent on the failings of the actors in the prosecutorial process rather than on flaws in the procedure itself. Thus, we are told that bad or corrupt lawyers result in cases being poorly handled (and trifling cases encouraged), prosecutors fearing actions for false imprisonment, and outright collusion with criminals. Charges might be lost because of pressure from friends or bribery. The suggestion throughout is that criminals escape through the weakness of their pursuers. It has been observed, however, that fatigue and expense were factors making prosecutors susceptible to bribery and collusion and it is this which provides the link between the failings of the prosecutor and the failings of the system which he attempted to utilize. It is to this latter question which I now wish to turn.

\section{B. CORONERS}

One way in which prosecutions might be facilitated is to reduce the number of procedures which must be followed before trial. In the 1840's, the Law Commissioners put the following question to members of the legal profession: ${ }^{64}$

62. R.E. Broughton (238).

63. F.P. Walesby (342).

64. Law Comm. VIIIth Rep. at 209; It should be recalled that as a matter of law it was not necessary to present a bill to a grand jury prior to trial where there had been a coroner's verdict, a party being triable on the inquest alone. 
Whether, where a verdict is found against a party upon a coroner's inquest, or in any other and what cases, the finding of a bill by a grand jury might be conveniently dispensed with?

While there were some who felt that " $[w]$ here bills found by Coroner's jury, it would appear unnecessary to present Bill to a second jury before trial.", ${ }^{65}$ the prevailing view within the legal profession was that Coroners' inquests were so poorly conducted as to be a totally inadequate basis for prosecution. One major concern of the "prosecutorial lobby" was that to dispense with the finding of a bill by a Grand Jury would result in too many technical acquittals of guilty persons. ${ }^{66}$ Typical of the criticisms made is that of one barrister who expressed the view that " $[t]$ he proceedings in general before coroners are so anomalous and irregular that they deserve little confidence in any respect. . .."

Although coroners worked "in haste" and "under circumstances admitting of very little consideration", ${ }^{68}$ a main criticism of coroners verdicts related to their formal defects rather than to substantive errors. Thus, for example, J. Barstow, Barrister-at-law, could "see no objection to the putting a party upon his trial on the coroner's inquisition alone, if proper care be taken in the drawing up of the inquisitions; at present not one in twenty will bear examination; indeed, it is this alone which renders the finding of a bill, for the same offence found by the inquisition, advisable in so many cases." 69

At least one contributor criticized the coroner's juries of London and Middlesex for, in effect, inquiring too closely into the matters before them thereby providing the party accused with more disclosure of the case against him than was desirable: ${ }^{70}$

.... the whole of the evidence which is the evidence which is to be brought forward at the trial is thus published beforehand, and thereby on the one hand prejudices are excited, and on the other hand facilities for escape are afforded, e.g. in the case of an alibi . . . .

\section{MAGISTRATES}

The preliminary inquiry before magistrates was also criticized for increasing the chances of a guilty person escaping. One submission to the Criminal Law Commission contained the suggestion that magistrates might fail to commit or hold to bail "from personal feelings or otherwise."71 This, however, is a criticism to which all judicial processes will be susceptible so long as humans are fallible. Except within very narrow limits it is not a failing such as may be remedied by legislative enactment.

The manner in which magistrates dealt with accused persons was however, remediable and it too drew criticism as being a factor tending to reduce the efficiency of prosecutions. C.N. Hastie thought that preliminary inquiries before magistrates would be beyond improvement if only it

65. Holding (290).

66. Fawcett (218); Lewin (220); Hogg (224); Temple (232); Paynter (244); Hays (252); Paris (254); Chapman (255); White et. al. (258); Grantham (273); Eyton (274); Greetham (276); Dalton (277); Attwood (279); Newstead (288); Poole (290); Rogers (302); Brooke \& Hall (311); Browne (314); Quilter (316); Adolphus (336); Roupell (339).

67. J.L. Adolphus (336).

68. Brooke \& Hall (311).

69. Barstow (223). Emphasis added.

70. Forsyth (253).

71. Leigh (226). 
were possible to discontinue "one practice very frequently adopted by magistrates and officers of justice .... I mean that of cautioning a prisoner not to criminate himself, and stopping his mouth in the very act of confessing the crime of which he stands accused." 72 Others too complained that too great an emphasis on providing protections for the accused tended to diminish the efficiency of preliminary inquiries before magistrates. ${ }^{73}$

Not all of the criticisms of this stage of the pre-trial process are capable of neat classification as being primarily prosecution or defence-oriented. Thus, one contributor complained that there was inadequate inquiry by magistrates and that the resulting depositions were so defective as to permit guilty persons to raise inconsistent defences at trial. One suspects however that the following comments are those of a (defence-minded) sheep attempting to cover himself in wolf's clothing: $:^{74}$

In many instances I have known depositions returned by the justices, wholly omitting the crossexamination of the witnesses called before the justices, and entirely omitting the evidence on the part of the accused. I think that this practice is objectionable on two grounds; first, it enables the prisoner at the trial to set up a new and inconsistent defence; and secondly, it is injurious to innocent parties who desire to rely on their first defence, by depriving them of the advantage which might be derived from giving on their trial additional evidence of consistent and corroborative facts.

\section{GRAND JURY}

Despite these defects the magistrates could normally be relied upon to commit (or bail) except in the most clearly misguided of prosecutions. Not so the grand jury. Accordingly, it was the latter which received the heaviest criticism of persons who sought to make pre-trial criminal procedure a more effective means of ensuring copious convictions.

One common criticism of the grand jury was that it added little to criminal procedure beyond increased trouble to the prosecutor ${ }^{75}$ and an additional opportunity for guilty persons to escape. ${ }^{76}$ In particular, the weaknesses of the grand jury were contrasted with the supposed strengths of the magistrates inquiry. Thus, for example, P. Bingham, Magistrate of the Police Court, Worship Street described the task of a grand jury as follows: ${ }^{77}$

The grand jury, composed of persons, for the most part, uninstructed in the law, are assembled, with much trouble and expense to themselves, for the purpose of deciding, on the ex parte statement of the prosecutor and his witnesses, whether there is a sufficient reason for putting an accused person on his trial.

A magistrate who is either learned in the law or advised by a clerk has already made a similar investigation ${ }^{78}$

72. Hastie (324); see also Gribble (312); Paynter (242).

73. For example, Attwood (279), objecting to the presence of lawyers as providing a means of communication with witnesses; Coke (309), objecting of the rules of evidence being too strictly applied, particularly as regards leading questions. See Lord Denman (212): "I am aware of no objection to the present mode and form of taking depositions before magistrates, and am strongly opposed to the practice of questioning the prisoner by any persons in authority."

74. Mellor (227).

75. See, for example, Deacon (216), Bingham (223), Hogg (225), Leigh (226), Roscoe (251), Chapman (255), Justices' Clerks Society (321), Laycock (329).

76. For example, Bosanquet (229), Temple (232), Justices' Clerks Society (322).

77. P. Bingham (223).

78. Id. 
under circumstances which afford a far better chance of arriving at a correct conclusion than those under which the case is presented to the grand jury; for the magistrate has the accused before him, and from his statements and demeanor alone, is often enabled to form a conclusive opinion as to the justice of the charge .... the grand jury never see the accused; are not, in general, made acquainted with the proceedings before the magistrate, and are often under considerable difficulty from the want of legal knowledge. It happens repeatedly that bills are thrown out, because the witness, whose testimony compelled the magistrate to commit, is not presented to the grand jury.

Another critic complained that the grand jury, "being usually entirely ignorant of the nature of legal proceedings, neither understand the legal elements of the charge nor what is the proper evidence to be produced in support of it, and who, not being conversant in the examination of witnesses, not infrequently fail in eliciting the required testimony." 79

Bosanquet thought that "the original use of a grand jury seems to be superseded by the comparatively modern practice of taking examinations and depositions upon oath, and in writing, by the committing magistrate" 80 and Thomas Paynter felt that the grand jury's "direct and proper functions as public accusers were substantially superseded by the more modern institution of justices of the peace." 81

One particularly serious failing of the grand jury as compared with this "more modern institution of justices of the peace" lay in the related issues of the failure of prosecution witnesses to appear before a grand jury and the facilitation of perjury before that tribunal. Bingham complained to the law commission that "[i]t happened repeatedly that bills are thrown out, because the witness, whose testimony compelled the magistrate to commit, is not presented to the grand jury". ${ }^{82}$ One magistrate's clerk pointed out that "crafty witnesses ... know they cannot be indicted for perjury before the grand jury" and claimed that "all prosecutions that are compromised are disposed of by losing the Bill before the Grand Jury".83 Similarly, R. Leigh, another magistrate's clerk, complained that "[i]t is before a grand jury where a witness has the best opportunity to commit perjury with impunity"84, while S.R. Bosanquet, a Barrister, stated that the grand jury provided "the most convenient opportunity for compounding felonies,

79. T. Paynter (243). The lack of expertise or knowledge in the grand jury is also criticized by Roscoe (251), Kelly (328) and Bingham (223). The inadequate presentation of evidence is discussed by Hargreaves (239), Roscoe (251), Coxwell (257), Rooker (264), Almack (272), Woodhouse (278-9), Adams (342).

80. Bosanquet (229).

81. Paynter (243), emphasis added. It may seem strange to modern ears to hear a magistrate's role equated to that of an accuser. In Jervis's Acts at 7, Archbold discusses the duties of Justices of the Peace (in terms well known to administrative lawyers) and, it is submitted, provides a valuable insight into a committing justice's role:

The jurisdiction of justices of the peace is ministerial or judicial. The judicial functions of justices consist of the trial of offenders at general or quarter sessions, and the hearing and adjudicating upon informations and complaints out of such sessions; their ministerial functions consist of receiving informations or complaints, for indictable offences, and also for offences or matters determinable in a summary way, - causing the party charged to appear and answer, whether by summons or by warrant, and taking bail, Ec. - and, in the case of summary convictions or orders, causing such conviction or order to be executed, by warrant of distress or of commitment.

82. P. Bingham (223).

83. J.M. Blagg (326).

84. R. Leigh (226). 
and shelters witnesses wilfully concealing the truth." ${ }^{85}$ A London magistrate also made mention of this problem: ${ }^{86}$

Old thieves . . . look to the grand jury for the chance of the bill being thrown out, sometizines by working upon, and sometimes bribing the prosecutor or principal witness .... it must be remembered that the grand jury inquire with closed doors, so that there is no check upon a witness whilst giving his evidence....

There were then four major criticisms of the grand jury which eminated from the "prosecutorial lobby": first, it was composed of persons ignorant of the law and inexpert in conducting their inquiries; second, the proceedings were too rushed to allow proper consideration of any individual case; third, honest evidence was inadequately presented and; fourth, perjury and compromise of prosecutions was facilitated. To a much lesser extent the grand jury system was also criticized as resulting in cases being thrown out for wrong reasons ${ }^{87}$ and as culminating in defective indictments. $^{88}$

Nevertheless, the value of the grand jury as a prosecutorial device was well recognized, for the return of a bill marked ignoramus could not give rise to a plea of autrefois acquit: ${ }^{89}$

Many cases will also occur to everyone acquainted with the subject in which the grand jury have thrown out bills believing the evidence insufficient to put the party on his trial, and the wisdom of that course has been justified by the subsequent discovery of further and more conclusive testimony, and which would have been useless in the event of a previous trial and acquitta] having taken place.

The grand jury, despite its defects, was also praised for encouraging "the co-operation of the higher and middle classes in the administration of justice." 90

\section{E. SUMMARY COMMENTS REGARDING INEFFICIENCY OF PROSECUTION}

It should not be thought that each and every of these criticisms was made or even would be approved by each contributor who showed a concern with the inefficiency or ineffectiveness of criminal prosecutions in 1843. Indeed, while the phrase "prosecutorial lobby" has been used as a shorthand means of referring to a grouping of criticisms tending towards calls for reform which would ease the burden of prosecution, there was nothing like a lobby group in the modern sense. It would be quite incorrect to view the situation as one in which two groups with solidified positions opposed each other on every issue. The fluidity of criminal procedure and the occasionally close relationship between fairness and efficiency has already been noted and on many occasions one contributor would make criticisms from both ends of the spectrum.

85. S.R. Bosanquet (229).

86. R.E. Broughton (238). Similar criticisms are made by Philcox (239), Holding (290), Browne (315), and Adams (342).

87. Cobbett (297) suggests that class bias induced grand juries to return bills "ignoramus" if preferred against a certain "quality" of person. Bishop (288) said:

I believe that grand juries in many instances throw out a bill because they think the offence too trifling for a prosecution, and yet the offender may, many times before he is detected, have been plundering the prosecutor to a great extent, which fact cannot be brought under the notice of the grand jury.

88. Helm (235).

89. Stone (265); see also White, et. al. (259).

90. Lord Denman, L.C.J. (212). 
Nevertheless, bringing criticisms of this sort together in one place demonstrates that a very potent argument might be put to the effect that pre-trial procedures in 1843 failed primarily as being ineffective means of ensuring conviction of the guilty. The "converse" criticisms are also very powerful indeed and it is to these that we will now turn.

\section{THE "FAIRNESS" LOBBY}

\section{A. ABUSE OF CRIMINAL PROCEDURE}

It has been noted above that there was a tendency for lawyers within the "prosecutorial lobby" to move from one piece of neutral empirical evidence - the fact that prosecutions were often compromised before trial - to the conclusion that guilty persons were escaping justice. The same facts might equally give rise to other conclusions: that criminal prosecutions were wrongfully commenced with the specific intention of abandoning the action before trial in return for monetary compensation, or quite simply that criminal actions were commenced on totally inappropriate grounds and abandoned when the mistake was realized.

Thus, the "fairness" lobby criticized private prosecutors for their ignorance and corruption. One Queen's Counsel, relying on his "long and extensive experience in criminal courts" suggested that "... many prosecutions are instituted which would be avoided by the exercise of a sound discretion ...."91 while the Doncaster Recorder, recommending the creation of a visitorial power in Magistrates, Judges, the AttorneyGeneral and the Solicitor-General states: "Very many prosecutions that have taken place within my experience would never have been heard if some such visitorial power had existed."92

Moving from effect to cause, T. Jefferson Hogg says that it is certain "that prosecutions are sometimes instituted with the object of obtaining compensation." ${ }^{93}$ Where such was the case, there was very little in the way of effective check upon the prosecutor: ${ }^{94}$

... the prosecutor, if really vindictive or pursuing a criminal charge for some unworthy motive or ulterior selfish object, can at present do so unchecked . . . .

Moreover, just as the lawyers concerned with the number of guilty persons escaping justice pointed an accusing finger at their professional colleagues, so too the "fairness lobby" suggested that improper prosecutions were encouraged by the legal profession.

The observation that "cases of trifling description are urged forward which should never come before a court" 95 has been noted above in a discussion of the likelihood of charges of unlawful imprisonment being brought against prosecutors. J. Eyton, a magistrate's clerk, makes it clear in his submissions that a combination of both legitimate and illegitimate considerations might influence a lawyer to encourage criminal prosecutions: ${ }^{96}$

91. M.D. Hill (210).

92. Sir G.A. Lewin (220); see also J. Richardson (270).

93. T. Jefferson Hogg (224); see also J. Eyton (274); "I have seen magistrates frequently committing persons for felony where a well-instructed lawyer would have left the prosecutor to his action for trover or other civil remedy."

94. Justices' Clerks Society (320).

95. William Trotter (330).

96. J. Eyton (274). 
... . [P]arties are frequently advised to adopt the criminal mode of proceeding in order to have the right to the article alleged to be stolen tried by jury (which it often substantially is by means of a criminal trial) at the expense of the public!

I am satisfied that owing to prosecutions being so much sought after by attorneys and magistrates' clerks', a far greater number of cases are brought forward than would otherwise be; and considering the number of acquittals, possibly there are more prosecutions than the amount of crime will really justify.

The first consideration is legitimate to the extent that it at least puts the client's best interest first. The second is contrary to both the public and to the client's interests, certain members of the profession looking after themselves rather too well: "Hungry practitioners prefer bills for the sake of costs, and it is not in general a bad speculation." 97

\section{B. CORONERS}

In a case of homicide the first official inquiry into the crime was through a coroner's jury which, typically, would be convened immediately upon the discovery of a corpse and would consist of local persons attempting to reach a verdict as soon as possible. The composition of the jury and the haste with which it acted was mainly criticized by the "prosecutorial lobby" as resulting in technically defective inquisitions.

Viewed from the perspective of an accused party however the coroner's inquest was unfair "especially as it seldom happens that the party accused is present at the inquest to offer any defence against the charge ...."98 The threat to such a person's reputation was viewed very seriously by the "fairness lobby": 99

The juries appear to consider themselves exempt from all legal rules; strong opinions are embodied in the verdict, and published, affecting deeply the characters of parties who have not the regular means of bringing the case to a fair investigation; witnesses are grossly insulted ... and the institution, as at present in operation, engenders and nurses many evils which it is the object of a fixed system of law to prevent.

Thus, the coroner's jury was said to publish defamation without providing the party defamed with a "regular means" of clearing his name. Witnesses (who might, presumably, be of higher social standing than the jurors) were insulted, and "many evils" were engendered.

Some indication of what these "many evils" might be is to be found in the submissions of C.S. Greaves, who said he "never knew an instance in which they [coroner's inquests] did any good ...." 100 The passage which follows is important too in that it demonstrates again how the same failings in one institution might result at once in prosecutorial inefficiency and in unfairness to innocent accused: ${ }^{101}$

If a coroner's jury find a verdict of murder, a prejudice is excited against the prisoner; if they find a verdict of manslaughter, the case on the part of the Crown is prejudiced, and perhaps a conviction for murder is unknown after a coroner's jury have found a verdict of manslaughter. If they find no verdict against anyone, the result generally is that no further inquiries are made, and many a murderer has thereby escaped a well-deserved punishment.

A practical example of the potential for unfairness at the hands of a coroner's jury was provided in the submissions of J. Stamners, Barrister-

97. Sir G.A. Lewin (220).

98. Richard Johnson (319).

99. T. F. Ellis (234).

100. C.S. Greaves (247).

101. Id. 
at-law. ${ }^{102}$ In $R$. v. Medhurst (1839) much ill-feeling in the neighbourhood was aroused against the accused following a homicide. As a result a coroner's inquest found "wilful murder" against him. When the matter came before a magistrate and, subsequently, before a grand jury, the committal and bill were respectively for manslaughter only. The accused was then tried simultaneously for murder (on the coroner's inquest) and manslaughter (on indictment) and "was only found guilty of manslaughter, and sentenced to three years ...." ${ }^{103}$ In commenting upon this case, Stamners drew attention to the unfairness of the coroner's inquest which, he suggested, arose from the local prejudices and ignorance of the jurors: ${ }^{104}$

Now it seems to me that if the finding of the coroner's inquest had been the foundation of the subsequent trial, without the intervention of a grand jury, the accused must have suffered greatly by it. I should not, therefore, think it advisable to substitute the verdict of a coroner's inquest, taken in the immediate neighbourhood of the crime, and often presided over by persons but very imperfectly acquainted with the principles of criminal law, for the finding of a bill by a grand jury, especially as I conceive the judge has the power, if he chooses to exercise it, of trying the prisoner upon the indictment first, and without reference to the finding at the coroner's inquest a power which may often be exercised with the greatest advantage to the ends of justice.

\section{MAGISTRATES}

The case of $R$. v. Medhurst (1839), and Stamner's commentary upon it, demonstrates how further preliminary inquiries before a magistrate and a grand jury might go to cure any unfairness resulting from the composition, haste or ignorance of a coroner's jury. However, these subsequent proceedings, much criticized by the "prosecutorial lobby", did not themselves stand as paradigms of fairness in action.

In the case of the magistrates' inquiry criticisms were made on a number of grounds. The discussion above, under the heading "Matters Preliminary to Trial in 1843 ", has shown that at its worst a preliminary inquiry might be conducted before an ignorant and biased magistrate, largely in the absence of the accused (unassisted by counsel or attorney) who would be unable to present evidence on his behalf, and might result in "depositions" which were only the most brief summary of what was actually said.

While the law was reasonably clear in 1843 that a prisoner ought to be present throughout his preliminary inquiry before a magistrate ${ }^{105}$ the effectiveness of this procedural protection was relatively easily undermined in practice. Mr. Browne, of Nottingham, complained to the law commission that the following procedure was employed in his region: ${ }^{106}$

The depositions are taken privately; and when completed, the prisoner is brought before the magistrate, and the depositions are read over in a hurried, and often very indistinct, manner to the witnesses, who are then sworn. The prisoner, in many instances, is altogether unprepared for attending to them properly.

Even if the accused person was permitted to be present throughout the whole examination of witnesses the magistrates' preliminary inquiry was "in general a one sided affair" 107 in which only the case for the prosecutor

102. J. Stammers (215).

103. Id.

104. Id.

105. 7 Geo. 4, c. 64, ss. 2, 3; see Archbold Jervis's Acts at 46; R. v. Arnold (1838) 8 Car. and P. 621,173 E.R. $645 ; 6$ and 7 Wm. IV, c. 114, s. 4.

106. Mr. Browne (314); see also J.P. Cobbett (293).

107. Sir G.A. Lewin (220). 
was investigated. The magistrate, in effect, was "only doing what the grand jury have by and bye to do again." 108 John Mellor argued that ${ }^{109}$

the preliminary examinations and inquiries on criminal charges before the justices are frequently attended with great hardship to individuals, who are committed to prison to abide their trial, without having witnesses on their behalf examined, and without a full inquiry into the case on both sides by the committing justices. In MANY instances I have known depositions returned by the justices, wholly omitting the cross-examination of the witnesses before the justices, and entirely omitting the evidence on the part of the accused.

Even where the right of an accused party to cross-examine prosecution witnesses was acknowledged by the justice of the peace (as it ought to have been $^{110}$ ) it was frequently a right more illusionary than real. The ignorant, introvert or confused accused would be unable to conduct an effective cross-examination unaided by counsel or attorney, and such assistance might lawfully be refused him, for, "[t]he justice may exclude an attorney or counsel if he likes". ${ }^{111}$

W. Grantham pointed out what he considered to be an anomaly in the law in that, on appearance before justices on a summary conviction matter the Prisoners' Counsel Act ${ }^{112}$ conferred a right to legal representation whereas a person accused of felony or misdemeanor had no such right. ${ }^{113}$ In such cases, a magistrate's refusal to permit legal representation "operates most unfairly to the prejudice of the prisoner."114 Grantham believed that "cases where a most satisfactory answer could have been given, had the prisoner been allowed that privilege, have been sent to trial." 115

The absence of counsel or attorney was detrimental to an accused party not only because he was thereby deprived of the assistance of a person who had developed forensic skills in the mustering and presentation of evidence but also because it more or less effectively precluded the possibility of any arguments on law being advanced. W.H. Owen drew attention to the consequences of this in his submissions to the law commissioners: ${ }^{116}$

I also consider that were attornies . . . empowered as a matter of right to attend as advisors of the accused before the justices, and to expound the law to them, that not half the committals that now do would take place, and which generally end in the bills being ignored by the Grand Jury, but with serious expense to the county .... [F]rom the nice distinction between breaches of trust, trespasses, and larceny, the former are generally mistaken for the latter.

Quite apart from these questions, which relate primarily to the lack of procedural protection for accused persons at a magistrate's preliminary enquiry, the "fairness lobby" criticized the magistrates themselves. One magistrates' clerk pointed out that there was "a positive inducement . . .

108. Id.

109. John Mellor (227); see also R. Read (291); Thomas Griffin (312).

110. See, for example 1 Chitty's C.L. 79; Chitty's Burn (1831) at 94.

111. Chitty's Burn (1831) at 94; Cox v. Coleridge 1 B. \& C. 37, 107 E.R. 15, Daubney v. Cooper 10 B. \& C. 237, 109 E.R. 438.

112. $6 \& 7 \mathrm{Wm}$. IV, c. 114 .

113. W. Grantham (273).

114. Id.

115. Id.

116. W.H. Owen (278). For other criticisms relating to the absence of defence counsel, see R. Read (291); J.P. Cobbett (293); R.S. Sowler (333). Other complaints which are not, perhaps, unrelated to the absence of counsel relate to the inadequate recording of depositions, the practice of examining the accused [J.P. Cobbett (293)] and a general lack of care by magistrates: "the investigation is not made so minutely as it ought to be" [R.S. Sowler (333)]. 
to the magistrates $\ldots$ to endeavour to procure the commitment of the prisoner, without which they have no means of obtaining payment of their ... fees." "117 This objection might also have been raised with respect to the magistrate's clerks ${ }^{118}$ upon whom the justices, who were most often lay. men unlearned in the law, were particularly dependent for advice.

The lack of legal expertise in the magistrates was criticized by James Richardson and Hamilton Richardson: ${ }^{119}$

Preliminary examinations and inquiries on criminal charges are at present conducted throughout the whole of England (except the metropolis and one or two other large towns) before an unpaid magistracy, selected in rural districts from the clergy and country gentlemen, and in towns from the wealthy merchants, bankers and professional men. Very few of these magistrates have received a legal education, and yet they are constantly called upon to consider and decide questions of considerable legal nicety, involving the liberties of those who are brought before them.

Such being the case, justices were "of course in a great measure under the guidance, on legal points, of the magistrates clerk". ${ }^{120}$ The clerk was typically an attorney, but this assistance to the magistrate did not render the system beyond criticism.

R.S. Sowler, in his submissions to the law commission, enumerated five main common criticisms relating to magistrate's clerks: ${ }^{121}$

1. They were "generally appointed from interest, and not for their efficiency";

2. They were "appointed by the magistrates from the area where their private business lies"; and, therefore,

3. They were "much influenced by private interests."

4. They were "paid by fees, which holds out inducements to accumulate cases, having the power to issue summons ad libitum"; and, lastly,

5. "[T]hey get almost all the prosecutions, which holds out inducements to send very trivial cases to be tried before a jury . . . ."

D. GRAND JURIES

Given the manifold failings of prosecutors, lawyers, coroners, magistrates and magistrate's clerks it is not unusual that the grand jury was viewed as both useful and necessary "as a cheque upon malicious and uncalled for prosecutions" 122 in 1843 . It may be somewhat surprising however, that this tribunal, "designed to be a means of protection to the citizen against the dangers of a false accusation" 123 was criticized by some as being of "no advantage whatever". ${ }^{124}$ One critic said that he was "firmly

117. Edward Coxwell (256).

118. See discussion, infra.

119. James Richardson and Hamilton Richardson (270).

120. Mr. Browne (314).

121. R.S. Sowler (333). In Staffordshire, the prosecutions apparently went regularly to the partner of the acting clerk of the peace rather than to the latter directly [Blagg (325)]. See also Mr. Browne (314), Robert Brandt (303), Robert Poole (290), W. Downes (279-80) pointing out that under the Municipal Act of the time only clerks to borough justices were prohibited from conducting prosecutions; J. Eyton (274); J. Rooker (267); John Morland (260); Edward Coxwell (256); W.T. Paris (254).

122. Sir G.A. Lewin (220).

123. New York State Law Commissioners quoted in Ashley Hibbard, "A Narrative and Exposure of the Evil of Secret Indictments by Grand Juries" (186?).

124. J. Barstow (222). 
of the opinion, from actual practice and experience, that the Grand Juries are merely an impediment and obstruction in the course of justice, and oftentimes a means of sore oppression." 125

The grand jury of 1843 filled two roles. It might act either as an additional check on a coroner or magistrate or as the tribunal of first inquiry which would find an indictment prior to apprehension of the party accused. In its first role the grand jury was open to criticism from the viewpoint of the accused in that it was manned by persons ignorant of law ${ }^{126}$ who acted in haste, often having 300 to 400 cases to dispose of in one week. ${ }^{127}$ Moreover, its hearings were both secret ${ }^{128}$ and ex parte, no evidence being heard for the accused. ${ }^{129}$ These evils might have been viewed as relatively insignificant defects in the greater scheme of pretrial inquiries were it not for two further facts: first, the dismissal of a bill by a grand jury did not have the effect of acquitting an accused; and second, it was said that the finding of a "true bill" in effect case an indelible stain upon a person's character regardless of what might happen at trial.

Thus, one lawyer felt that "it seems scarcely treating a prisoner fairly to commit him for trial, and because the grand jury ignore the bill against him, he may still remain liable to be apprehended again, and go through all the anxiety and expense of preparing for trial a second or third time." 130 Even if a case lost before a grand jury would most assuredly never have been resurrected by a vindictive prosecutor, the return of a bill "ignoramus" was still viewed by some as "not so satisfactory as if the prisoner had been acquitted, after a fair inquiry in the face of the country." 131

The ease with which a proper prosecution might be lost before a grand jury has already been noted. Thus, it was felt by some that the innocent accused would ${ }^{132}$

much rather be acquitted in open court, confronted by his prosecutor before the face of the whole public, and have it shown to the world that there was no proof against him, rather than have the Bill thrown out by the Grand Jury, sitting in a private room, and conducting their inquiry no one knows how; where he might be liable to the imputation of having connived with the prosecution and witnesses, or that he escaped by the favour of some of the witnesses not telling the whole truth, or from the Grand Jury not knowing how to frame their questions, so as to elicit the important proofs on which the case hinged.

On the other hand, if the matter went to trial and resulted in acquittal, it was felt that the ultimate acquittal would do little to fully restore the accused's good name: "if, in addition to the magistrates' commitment, a Grand Jury also find a true Bill, a verdict of acquittal by a Petty Jury will have but little effect in removing the stain cast upon the character of an innocent party by these two preliminary solemn inquiries." ${ }^{133}$

125. J.M. Blagg (326).

126. P. Bingham (223); R.E. Broughton (238).

127. R.E. Broughton (238).

128. J. Barstow (222); R.E. Broughton (238).

129. P. Bingham (223); R.E. Broughton (238); J. Roscoe (251).

130. Mr. Browne (314).

131. J. Roscoe (251).

132. J. M. Blagg (326).

133. Thomas Kelly (328). 
The effect of the return of a "true bill" on a person's character was also emphasized by critics of the grand jury in its second role. The direct preferral of bills was called a "great oppression" by one critic. ${ }^{134}$ A Montreal businessman who had himself been the victim of direct preferral has indicated how this "oppression" occurred: ${ }^{135}$

$\ldots$. every man is liable, particularly if he has been engaged in large and complicated commercial transactions, and no matter how innocent, to be treated as a felon, thief, or murderer, and published as such, without having had a chance to say a word in his defence, or even knowing that such a charge has been made against him, until he reads it in the public press, at the same time as hundreds of thousands read it; and that, practically, this is one stage of condemnation which is directly contrary to the spirit of English Criminal Law, and to all ideas of justice and fairness.

In such a case there would be no pre-trial disclosure of the basis of the charge equivalent to that which usually occurred at a magistrate's examination. ${ }^{136}$

Finally, direct preferral was criticized as enhancing the utility of the criminal process as a means of bringing pressure to bear on civil claims. According to Ashley Hibbard, " $[t]$ he instances are numerous in which unprincipled and unscrupulous lawyers have . . . made use of the facilities afforded by the practice of secret indictments before Grand Juries, to extort money from unfortunate and timid persons; and they do this in most cases with perfect impunity." 137

\section{REFORMS RECOMMENDED TO THE LAW COMMISSION}

It is one of the main objectives of this article to demonstrate that, contrary to received historical wisdom, the first of Sir John Jervis' Act fell far short of being a radical enactment and was, in fact conservative in the deepest sense of that word. The degree to which any enactment may be classified as "revolutionary" is largely a factor of the extent to which it makes major changes to the status quo in response to perceived problems.

This statement embraces three sub-tests of radical innovation:

1. Does the legislation in question address itself to contemporaneous perceptions of problems in the pre-reform law and practice? To what extent does it respond to calls for reform made by reasonably informed observers?

2. Does the legislation in question introduce a marked change in the

3. Does the legislation in question require a marked change in administrative or judicial practices?

The first test concerns a normative evaluation of the adequacy of reform. The last two deal with a relatively simple question of fact: the quantum difference between the old and the new.

134. C.S. Greaves (247).

135. Supra n. 123 at 31.

136. S. Greetham (276). James Beesley (317) points out, however, that the grand jury could be made "an engine of great oppression" even where the matter had previously been before a magistrate; for example, where a bill was presented on one issue and evidence presented on another: "A prisoner is often committed for one offence and tried for another; this is a great grievance."

137. Supra n. 123 at 47. 
Taking the normative issue first, the manifold criticism of pre-trial inquiries in 1843 have already been noted. Not surprisingly, the perceived defects gave rise to many and varied calls for reform. There were, for example, calls for the appointment of public prosecutors ${ }^{138}$ or, alternatively, for a standardization of the custom whereby clerks conducted the prosecution of cases heard in their courts. ${ }^{139} \mathrm{~A}$ number of critics believed that the appointment of stipendiary magistrates throughout the whole of the country would go far to remedy the defects of pre-trial procedure $^{140}$ while others suggested that a change in the method of paying clerks and justices of the peace was needed. ${ }^{141}$ There were calls alternatively for the abolition of coroners' juries, ${ }^{142}$ their drastic reform, ${ }^{143}$ and a reduction of their role. ${ }^{144}$ Similarly, other contributors felt that the grand jury system was in need of reform,,$^{145}$ abolition ${ }^{146}$ or dimunition. ${ }^{147}$ It was also suggested that the procedure followed at magistrates' preliminary inquiries ought to be standardized ${ }^{148}$ and there were variously suggestions that accused persons ought to be entitled as of right to representation by counsel or attorney, ${ }^{199}$ that legal representation for the defence ought never to be permitted, ${ }^{150}$ that more ${ }^{151}$ evidence for the accused ought to be received at preliminary inquiries before magistrates. Reforms were also suggested relating to the methods of examining accused parties ${ }^{152}$ and of taking depositions at magistrates' examinations. ${ }^{153}$

The various reforms proposed were often seen as being inextricably interlinked. Thus, it was said the grand jury might be dispensed with only if magistrates' inquiries were improved, ${ }^{154}$ higher quality persons were appointed as coroners, ${ }^{155}$ or public prosecutors were appointed, ${ }^{156}$ to name but a few "alternatives". Again, the reforms suggested were frequently such that they might at once ease the burden of prosecution (and, therefore, ensure more frequent conviction?) and make the pre-trial process fairer to the accused.

The discussions centering on the proposal of a public prosecutor provide a good example of the way in which these various threads were interwoven. They are also valuable as indicating the historical roots of

138. E.g. Hill (210); Denman (211); see discussion, infra.

139. E.g. Justices' Clerks Society (321).

140. E.g. Stammers (214); Richardson (270); Downes (279).

141. E.g. Stone (306); Justices' Clerks Society (321); Sowler (333).

142. E.g. Ellis (234); Greaves (247).

143. E.g. Mellor (227); Greaves (247).

144. E.g. Roscoe (251).

145. E.g. Hargreaves (239); Paynter (243).

146. E.g. Barstow (223); Cobbett (297); Robins (309).

147. E.g. Deacon (216); Leigh (226); Bosanquet (228); Greaves (247).

148. E.g. Mellor (227); Sowler (333).

149. E.g. Owen (278); Read (291); Cobbett (293).

150. E.g. Attwood (279).

151. E.g. Mellor (227); Griffin (312).

152. E.g. Fawcett (218); Denman (212); Paynter (242); Cobbett (293).

153. E.g. Lewin (220); Cobbett (293).

154. E.g. Mercer (268); Downes (279); Stone (301).

155. E.g. Morland (260); Woolrych (283).

156. E.g. Helm (235); Trotter (331). 
the oft-repeated (but seldom heeded) incantation that Crown prosecutors fulfill a quasi-judicial, ${ }^{157}$ not an adversarial function.

Predictably, one major thrust in the argument for the creation of an office of public prosecutor was that it would increase the efficiency of criminal prosecutions, resulting in less offences going unprosecuted and in less frequent acquittals of guilty persons. It would become less common for "crimes of great magnitude [to] go unpunished." 158 This would be so partly because injured parties would be more willing to institute criminal proceedings, ${ }^{159}$ and partly because it would prevent the compromise of criminal actions. ${ }^{160} \mathrm{G}$.J. Fielding thought that "the greater certainty of apprehension and of vigorous proceedings being afterwards taken against offenders would no doubt prevent much crime." ${ }^{161}$ W.H. Woolrych also suggested that the appointment of a public prosecutor would result in more thorough preparation and a more effective presentation of the prosecution case. ${ }^{162}$ It was even suggested that the efficiency of the prosecutorial process might be further enhanced by the appointment of a public prosecutor in that such an official might replace the grand jury both by reviewing magistrates' committals, ${ }^{163}$ and by drawing indictments ${ }^{164}$ (probably, it was suggested, with less technical defects than the indictments of grand juries. ${ }^{165}$ ) Indeed, one contributor seems to have suggested that the appointment of a public prosecutor, who would conduct his own informal inquiry and draw an indictment might stand in place of both the magistrates preliminary inquiry and the grand jury investigation. ${ }^{166}$

More surprising perhaps is the support offered for the appointment of public prosecutors on the grounds that this would enhance the fairness of the pre-trial process towards the accused party.

There was, for example, a substantial body of opinion to the effect that the "exercise of a sound discretion" 167 which would flow from the appointment of public prosecutors would result in less prosecutions being brought forward. This would result, in part at least, from a reduction in the number of prosecutions instituted "with the object of obtaining compensation". ${ }^{168}$ It was felt too that public prosecutors would result in less abuse of the criminal process by "needy, sharkish and often unprincipled practitioners" acting only in their own self-interest. ${ }^{169}$

The very high standard of fairness which it was assumed public pros-

157. Whatever that term may mean. This question has long plagued administrative lawyers. See W. Pue, Natural Justice in Canada (1981) ch 2.

158. Poole (290).

159. Gribble (312); Hastie (324).

160. Denman (211); Brandt (303); Blagg (326).

161. Fielding (332).

162. Woolrych (282).

163. Deacon (216); [Roscoe (251)].

164. Helm (235); Brandt (303); [Trotter (331)].

165. Helm (235).

166. Roscoe (251).

167. Hill (210).

168. Hogg (224).

169. Browne (314); see also Blagg (326); Trotter (330). 
ecutors would import to the criminal process was reflected in the submissions of the Justices Clerks Society: ${ }^{70}$

The public prosecutor would then feel it to be his duty to see that justice was done to the prisoner, and that, while no unfair attempt should be allowed to be made on his behalf to pervert the course of justice, every opportunity should be given him of endeavouring to rebut the charge and establish his innocence....

So much was expected of the prosecutor in the preparation of criminal trials that it was thought by some that the creation of such a post would not only permit the grand jury to be disposed with; it would act also as a double check on the excesses of magistrates. E.E. Deacon, for example, felt that "the finding of a bill by a grand jury might be conveniently dispensed with after a previous inquiry before the committing magistrates." $171 \mathrm{Nev}$ ertheless, he acknowledged that it was questionable whether magistrates should have this much power and suggested that, if they were not to be trusted this far, "a responsible legal officer might be appointed for each county, or for a certain district, as public prosecutor, to whom the examinations before the magistrate might be transmitted, and who should have the sole power of deciding whether the accused should be put upon his trial, and issue his fiat before any indictment was preferred." 172

\section{THE ACHIEVEMENTS OF SIR JOHN JERVIS' ACT}

There was, then, a very broad range of proposals, touching on every stage of pre-trial inquiry, put to the English law commissioners in 1843. However, the first legislative response to this call for reform did not appoint public prosecutors, did not abolish grand juries, did not extend the system of stipendiary magistrates throughout the country. It may be said that the "Act to facilitate the Performance of the Duties of Justices of the Peace out of Sessions within England and Wales with respect to persons charged with indictable offences" did recognize the general preference the legal professions had expressed for magistrates inquiries over other forms of pre-trial investigation. This is reflected by the fact that the Act extended the jurisdiction of Justices of the Peace to cover misdemeanors not against the peace and authorized the issuance of a warrant and committal to trial even if the alleged offence had not been committed within the magistrates territorial jurisdiction. ${ }^{173}$

It was not however, primarily intended to reform. Indeed, the recital in

170. Justices' Clerks Society (322). The same trust was not, apparently, accorded to police officers nor to magistrates. James Beesley (318) wrote:

There exists in the minds of many magistrates a desire to support their own commitments; and to such an extent are they influenced by this feeling, that it is by no means an uncommon circumstance to see them, during the trial of a prisoner, in communication with the attorney for the prosecution . . . .

[Policemen's evidence] "should always be corroborated. These men pride them. selves on the number of committals through their exertions, and also of the convictions upon their evidence .... they consider it a part of their business to hunt a prisoner to conviction in some way or another, and a part of their talent is how to make evidence, and give evidence, and in justice to the accused, their evidence ought always to be corroborated."

171. Deacon (216).

172. Id.

173. See Archbold, Jervis's Acts (1848) at 7, 20,21 (212). See, however, Chitty's Burn(1831) at 97-98. 
section 1 of the Act emphasizes the importance of the Act as consolidating and clarifying existing law: ${ }^{74}$

Whereas it would conduce much to the improvement of the administration of criminal justice within England and Wales, if the several statutes and parts of statutes relating to the duties of

Her Majesty's justices of the peace therein with respect to persons charged with indictable offences were consolidated, with such additions and alterations as may be deemed necessary, and that such duties should be clearly defined by positive enactment . . . .

With respect to the actual conduct of preliminary examinations the Act made little change in positive law and none in predominate practice. The Act may, in this respect, be evaluated having regard to six main points:

1 . The power of justices to compel the attendance of witnesses (s. XVI);

2. The duty of justices to take statements in the presence of the accused (s. XVII);

3. The right of the accused to cross-examine prosecution witnesses (s. XVII);

4. The duty of justices to first caution accused persons and then to ask them if they wish to make a statement (s. XVIII);

5 . The discretion in the magistrate as to whether or not to permit defence counsel or attorney to be present (ss. XVIII, XIX);

6 . The right of the accused to have copies of depositions taken before magistrates made available to him (s. XXVII).

\section{A. JUSTICES' POWER TO SUMMONS WITNESSES}

As regards the power to compel attendance of witnesses, section 16 of the Act provided as follows:

XVI. And be it enacted, that if it shall be made to appear to any justice of the peace, by the oath or affirmation of any credible person, that any person within the jurisdiction of such justice is likely to give material evidence for the prosecution, and will not voluntarily appear for the purpose of being examined ... against the accused, such justice may and is hereby required to issue his summons to such person....

This is a remarkably one-sided provision, by its express terms authorizing magistrates to summons prosecution but not defence witnesses, a strange provision, indeed, in an Act said to embody "the true English spirit of fairness towards the accused". ${ }^{.75}$ The wording here seems however to be similar to that of previous statutes and the received orthodoxy mitigated the potential for unfairness arising from the words used. In 1619 , Dalton expressed his view that apparently one-sided statutes had to be read in light of the inherent fairness of English law! !76 $^{176}$

It seemeth just and right, that the Justice of Peace who taketh information against a felon or person suspected of felony, should take and certify as well such information, proof, and evidence, as goeth to the acquittal or clearing of the prisoner; as such as makes for the King and against the prisoner; for such information, evidence or proof taken, and the certifying thereof by the Justice of Peace is only to inform the King and his Justice of Gaol delivery, etc., of the truth of the matter.

Dealing with a precursor to s. 16 of Sir John Jervis' Act, Chitty had expressed the view that "upon the reasonable request of the defendant, the magistrate has a similar power to bring before him any witness who may be able to give material evidence in his behalf." 177

174. Emphasis added.

175. Supran. 3.

176. Dalton, Countrey Justice (1619) at 274.

177. 1 Chitty's C.L. (1819) 62 [77]. 
As this had become the accepted view of the law regarding justices' powers to compel the attendance of witnesses long before $1848^{178}$ it is surprising that Sir John Jervis' Act did not make such power express, the more so as the Act purportedly aimed to make magistrates' powers and duties "clearly defined by positive enactment..."179

\section{B. RIGHT OF ACCUSED TO BE PRESENT AND TO CROSS- EXAMINE}

Section 17 of the Act dealt with the rights of the accused to be present during the taking of depositions and to cross-examine prosecution witnesses and provided that, at the time of trial, it was only if "it be proved that such deposition was taken in the presence of the person so accused, and that he or his counsel or attorney had a full opportunity of crossexamining the witness, then .... . it shall be lawful to read such deposition as evidence in such prosecution ...." The section stated that before committal or bail, a Justice "shall, in the presence of such accused person, who shall be at liberty to put questions to any witness produced against him, take the statement . . . of those who shall know the facts and circumstances of the case ...."

This too was little more than a re-statement of previous law, conferring no new protections to accused parties. ${ }^{180}$ On the other hand, it has been noted that some magistrates, at least, had found a means of complying with the letter of the law as regards such procedural protections while denying its spirit entirely. ${ }^{181}$ Again, we may note that it is somewhat surprising in light of its stated aims (much less its alleged accomplishments!) that all potential for misconstruction was not removed by the Act of 1848.

\section{WARNING AND STATEMENT FROM ACCUSED}

Sir John Jervis' Act is however, noteworthy in providing that, prior to taking a statement from an accused the Justice "shall state to him, and give him clearly to understand, that he has nothing to hope from any promise of favour, and nothing to fear from any threat which may have been holden out to him to induce him to make any admission or confession of his guilt, but that whatever he shall then say may be given in evidence against him upon his trial . .." 182 This litany, is well known to the modern criminal lawyer, and is repeated, almost without change, in Canada's Criminal Code. Archbold praised the enactment of such a caution saying, "[t]his address to the accused is in that true spirit of fairness towards him which distinguishes the administration of criminal justice in this country, from its administration in any other country in Europe."183

178. Archbold Jervis's Acts (1848); Law Commission VIIIth Rep., Ch. I, Sect. 7, Arts. 25, 26; Chitty's Burn (1831) 95; Chitty's C.L. (1819) 64 [79].

179. See text to n. 174, supra.

180. See Archbold, Jervis's Acts (1848) at 46; Law Commission VIIIth Rep., Ch. I, Sec. 7, Arts. 28-31; Chitty's Burn (1831) at 94; 1 Leach, 202, 309, 500, 503, a; 5 Mod. 163; $R$. v. Commins, 4 D. \& R. M.C. 94; R. v. Arnold (1838) 8 Car. and P. 621, 173 E.R. 645; Chitty's C.L. (1819) 63 [79]. See W.R. Cornish, supra n. 7.

181. See text to notes $121 \cdot 122$, supra

182. Section 18.

183. Archbold, Jervis's Acts (1848) 48 . 
It had, however, long been the law of England that a prisoner had a right to make a statement and that he ought not to be put under pressure to do so. ${ }^{184}$ Chitty reported in 1819 that the common practice "when a party is brought before a magistrate" was to caution him "that he is not bound to accuse himself, and that any admission may be produced against him at his trial." ${ }_{185}$ This practice had apparently solidified into an obligation upon the magistrate by 1838 for, in $R$. v. Arnold Lord Denman, C.J. stated as follows: ${ }^{86}$

A prisoner is not to be entrapped into making any statement; but, when a prisoner is willing to make a statement, it is the duty of magistrates to receive it; but magistrates before they do so ought entirely to get rid of any impression that may have been on the prisoner's mind, that the statement may be used for his own benefit; and the prisoner ought also to be told that what he thinks fit to say will be taken down, and may be used against him on his trial.

In this respect, therefore, Sir John Jervis' Act was radical in legislation though conservative as against both common law and common practice. Nonetheless, such express enactment was not without its significance as a means of educating a lay magistracy as to what they ought, in any event, to have been doing. Archbold's conclusion that "it is enacted now, for the purpose of making the practice general and uniform"187 is undoubtedly correct.

\section{DEFENCE REPRESENTATION BY COUNSEL OR ATTORNEY}

In England in the 1840's an accused person had no right to legal representation at preliminary inquiries, "the permitting such assistance ... [being] discretionary with the magistrate or Court." ${ }_{188}$ This unusual state of the law was justified by Chitty on the grounds that preliminary inquiries were not conclusive and presumably, therefore, not prejudicial to an accused no matter what the result (although he might be imprisoned for months as a consequence!): ${ }^{189}$

It may be well to observe, that a prisoner, when examined before a magistrate on a charge of felony, is not entitled, as of right, to have a person skilled in the law, or any other, present as an advocate on his behalf, it being a preliminary investigation only, and not conclusive on him.

In this respect, Sir John Jervis' Act made no change whatsoever despite the very persuasive arguments made to the law commission that legal representation should be permitted as of right at magistrates' preliminary inquiries. The Act makes no express reference either to a right to legal representation or to a magistrate's authority to exclude counsel, the latter presumably being enshrined and enhanced by section $19:^{190}$

... the room or building in which such Justice or Justices shall take such examinations and statement as aforesaid shall not be deemed an open court for that purpose; and it shall be lawful for such Justice or Justices, in his or their discretion, to order that no person shall have access to

or be or remain in such room or building without the consent or permission of such Justice or Justices, if it appear to him or them that the ends of justice will be best answered by so doing.

184. Law Commission Digest Arts. 24, 34; Chitty's Burn (1831) at 96, 97, and 99; Chitty's C.L. (1819) at $67[84], 68 ;[84,85]$.

185. Chitty's C.L. (1819) 68 [85].

186. Supra n. 180 at 621.622 .

187. Archbold, Jervis's Acts (1848) 48. See W.R. Cornish, supra n. 7.

188. Law Commission, Digest Art. 34. See also Chitty's Burn 94, Cox v. Coleridge, supra n. 111; Daubney v. Cooper, supra n. 111.

189. Chitty's Burn (1831) 99; this observation bears comparison with arguments sometimes advanced in modern administrative law. See W. Pue, Natural Justice in Canada (1981) 55 ff.

190. Emphasis added. 


\section{E. RIGHT TO RECEIVE COPIES OF DEPOSITIONS}

Section 27 of Sir John Jervis' Act states that a committed or bailed accused was entitled to receive copies of the depositions taken at his preliminary inquiry:

$\ldots$ at any time after all the examinations aforesaid shall have been completed, and before the first day of the assizes or sessions or other first sitting of the Court at which any person so committed to prison or admitted to bail as aforesaid is to be tried, such person may require and shall be entitled to have, of and from the officer or person having the custody of the same, copies of the depositions on which he shall have been committed or bailed, on payment of a reasonable sum for the same, not exceeding at the rate of $11 / 2 \mathrm{~d}$. for each folio of ninety words.

This clearly is a very important provision as regards fairness to the accused who, especially if his lawyer were not present at the preliminary enquiry, would need to review the depositions in order to prepare his case adequately for trial. Unjust as it may seem, there was a time in English law when the prosecutor ${ }^{191}$ but not the accused ${ }^{192}$ would be permitted copies of the depositions. This, however, had been remedied some time before 1848 and, in this respect too, Sir John Jervis' Act simply re-enacted existing law. ${ }^{193}$

\section{CONCLUSION}

Having considered the criticisms of existing pre-trial inquiries made to the Law Commissioners in 1843 and the reforms which they recommended it is apparent that there was a widely perceived need for radical reform. Sir John Jervis' Act did not respond to this call, making very little change to the law regarding the procedures used by Justices of the Peace in their preliminary examinations. The one "change" which was made, relating to the warning given to accused persons before taking statements from them, arguably simply codified common law. It certainly did not call for drastic alteration in predominant practice. The most radical changes called for by reformers - the abolition of grand juries, the appointment of public prosecutors, even the entrenchment of a right to legal representation - went unheeded in 1848.

The Act, therefore, falls far short of the praise lauded upon it by Archbold in the passage quoted at the beginning of this essay, for it fails in all three of these tests of radical innovation outlined above. It certainly did not, as some have contended, "establish" the preliminary inquiry as it is now known.

The criticisms of the existing system came from all sides and touched upon each stage of pre-trial enquiry. There was, however, no obvious consensus on the changes which might usefully be made and in such circumstances it is not unusual that the conservative maxim "no change is better than any change" reasserted itself.

Nevertheless, the utility of such consolidating legislation at a time when the magistracy consisted mostly of local gentlemen untrained in the law should not be underestimated. The Act no doubt had great educational benefit. It was not retrograde, not an oppressive piece of legislation but simply over-praised.

191. Chitty's C.L. (1819) 72 [89].

192. Id. at 67 [83].

193. $6 \& 7$ Wm. IV, c. 114, s. 3; Archbold, Jervis's Acts (1848) 79. 